$<$ 症例報告 $>$

高齢で多発性両側性肺動静脈瘻の手術を施行した

Rendu-Osler-Weber 病の一例

$\begin{array}{lllll}\text { 三根生和明 } & \text { 藤岡 } & \text { 精二 } & \text { 市木 拓 } \\ \text { 岩田 } & \text { 猛 } & \text { 河野 } & \text { 修興 } & \text { 日和田邦男 }\end{array}$

\begin{abstract}
＜要 約 > 症例は70歳女性. 幼小児期より鼻出血を頻回に認め, 35歳時頃から Hugh-Jones II 度の労 作性呼吸困難を自覚していた。同時期に胸部 X 線写真上，異常陰影を指摘されたが放置していた。 1990 年 9 月旅行中, 呼吸困難の増悪を認め, 歩行時に急激な呼吸困難を自覚した直後, 意識消失し, 救急車 にて近医に入院した。その際胸部 X 線写真・CT・DSA 等で肺動静脈瘻と診断された。加療目的で10月 1 日, 当院に紹介され入院した。肺動静脈瘦は 6 個存在し, 濃厚な鼻出血の家族歴を認めたため RenduOsler-Weber 病に伴う肺動静脈瘻と診断した。 100\%酸素投与下で, 簡便法を用いて求めたシャント率は 56.5\%であった。入院時には, room air 呼吸下で $\mathrm{PaO}_{2} 39.8 \mathrm{Torr}, \mathrm{SaO}_{2} 75.4 \%$ 之高度の低酸素血症を 示し，その後も急速に増悪をきたしたため，肺動静脈瘻切除目的で10月 5 日左肺部分切除術 $(\mathrm{S} 3,4,5$, 8)を施行した。術後経過は良好で, 11 月 2 日の退院時の動脈血ガス分析(room air 呼吸下)は $\mathrm{PaO}_{2} 76.4$ Torr, $\mathrm{SaO}_{2}$ 95.7\%を示した. $100 \%$ 酸素投与下で，簡便法を用いて求めたシャント率は $24.6 \%$ と改善を 示した.
\end{abstract}

Key words：多発性両側性肺動静脈㾞, 高柃患者, 手術療法, 低酸素血症, Rendu-Osler-Weber 病

\section{はじめに}

肺動静脈癭は1879年 Churton ${ }^{11}$ とり初めてその剖 検例が報告された。本邦では1954年佐野ら゙2が肺血管 腫として第一例を報告して以来, 今日までに約200例が 報告されている．年齢構成では20歳未満の若年者が約 半数を占め, 70 歳以上は $1 \%$ 以下である，我々は70歳 之高齢の多発性両側性肺動静脈瘦の手術例を経験した ので報告する。

\section{症例}

患者：70歳，女性.

主訴：労作性呼吸困難。

既往歴：特記すべきことなし。

家族歴：曾祖母が鼻出血で死亡. 祖父, 祖父の兄弟, 母親，妹，4人の子供全てに鼻出血傾向あり。次男に 胸部 X 線写真で異常陰影あり (因 1 ).

現病歴：子供の頃より鼻出血傾向があった。1955年 (35歳)頃, 検診で胸部 X 線写真上胸膜瘦着を指摘され

K. Mineoi, S. Fujioka, H. Ichiki, T. Iwata, N.

Kohno, K. Hiwada：愛媛大学医学部第二内科

受付日：1991。2.12 採用日：1991. 3. 20

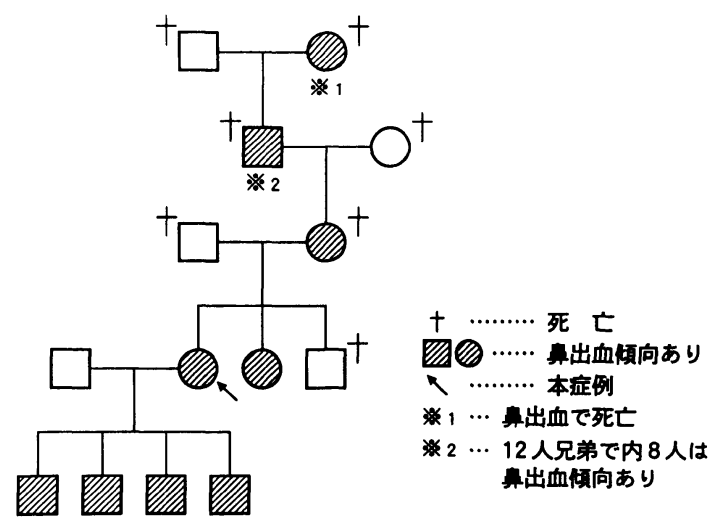

図 1 家系図

たが特に問題ないといわれていた。同時期より労作時, 呼吸困難（Hugh-Jones II 度）を認めるよらになったた め, 強い労作は意識的に規制していた。1990年 9 月， 旅行中, 歩行時に呼吸困難が急激に増悪し（HughJones $\mathrm{V}$ 度）意識消失をきたし，救急車で近医に入院 した，頭部 CT では異常なく，胸部 CT・DSA 等で肺 動静脈瘦と診断された。精査加療のため 10 月 1 日当科 へ紹介され入院した。 
入院時現症：身長 $156 \mathrm{~cm}$ ，体重 $55 \mathrm{~kg}$. 脈拍 $90 /$ 分・整， 呼吸数 $20 /$ 分, 血圧 $138 / 80 \mathrm{mmHg}$. 口唇, 両手指にはチ アノーゼがあり，バチ状指も認めた。口腔粘膜に血管 拡張を認めた，胸部では，左前胸部の第 3 肋間鎖骨中 線上认最強点を有し，吸気時增強する Levine II/VI の 血管性雑音を聴取した，腹部では肝，脾，堅を触知せ ず，神経学的には異常を認めなかった。

\section{表 1 入院時検査成績}

（H 2 年10月 2 日）

\begin{tabular}{|c|c|c|c|}
\hline \multicolumn{4}{|l|}{ 血液 } \\
\hline $\mathrm{RBC}$ & $562 \times 10^{4} / \mathrm{mm}^{3}$ & $\gamma$-GTP & $10 \mathrm{IU} / l$ \\
\hline $\mathrm{Hb}$ & $17.5 \mathrm{~g} / \mathrm{d} l$ & LAP & $41 \mathrm{IU} / l$ \\
\hline $\mathrm{Ht}$ & $51.6 \%$ & ZTT & $21 \mathrm{U}$ \\
\hline WBC & $4600 / \mathrm{mm}^{3}$ & TTT & $27 \mathrm{U}$ \\
\hline Plt I & $19.0 \times 10^{4} / \mathrm{mm}^{3}$ & BUN & $11 \mathrm{mg} / \mathrm{d} l$ \\
\hline CRP & $(-)$ & $\mathrm{Cr}$ & $0.8 \mathrm{mg} / \mathrm{d} l$ \\
\hline \multicolumn{2}{|c|}{ 血液生化学 } & \multicolumn{2}{|l|}{ 血清電解質 } \\
\hline $\mathrm{TP}$ & $7.1 \mathrm{~g} / \mathrm{d} l$ & $\mathrm{Na}$ & $140 \mathrm{mFq} / \mathrm{l}$ \\
\hline Alb & $3.3 \mathrm{~g} / \mathrm{d} l$ & K & $4.5 \mathrm{mEq} / l$ \\
\hline$A / G$ & 0.9 & $\mathrm{Cl}$ & $108 \mathrm{mEq} / \mathrm{l}$ \\
\hline T.Bil & $1.1 \mathrm{mg} / \mathrm{d} l$ & \multicolumn{2}{|c|}{ 動脈血ガス分析 } \\
\hline D.Bil & $0.2 \mathrm{mg} / \mathrm{d} l$ & $\mathrm{pH}$ & 7.41 \\
\hline $\mathrm{ChE}$ & 189 Ch. EU & $\mathrm{PaO}$ & 39.8 Torr \\
\hline GOT & $16 \mathrm{IU} / l$ & $\mathrm{PaCO}$ & 32.9 Torr \\
\hline GPT & $15 \mathrm{IU} / l$ & $\mathrm{SaO}$ & $75.4 \%$ \\
\hline LDH & $129 \mathrm{IU} / l$ & シャント率 & $56.5 \%$ \\
\hline ALP & $179 \mathrm{IU} / l$ & & \\
\hline
\end{tabular}

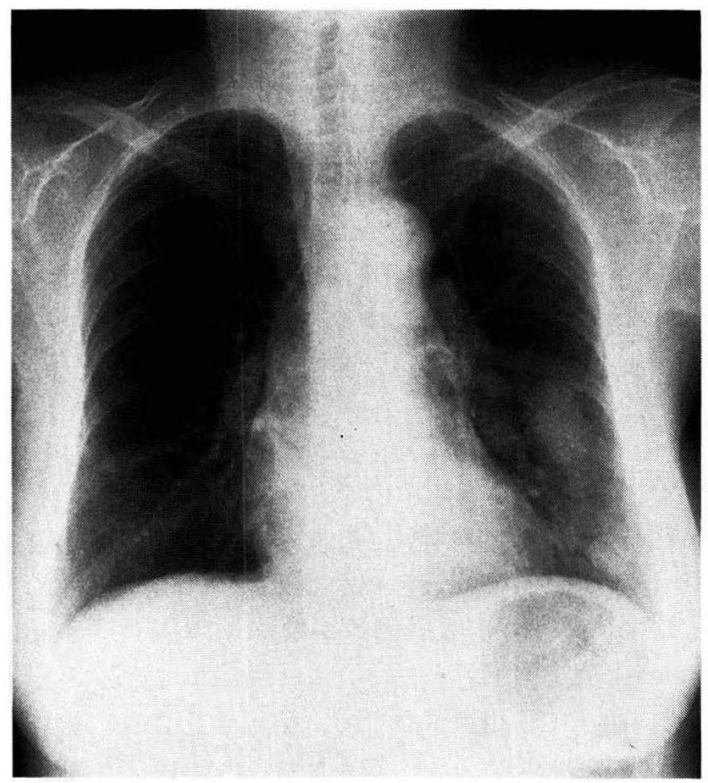

図 2 入院時の胸部 X 線写真
入院時検查成績: 末梢血液像は赤血球 $562 \times 10^{4} /$ $\mathrm{mm}^{3}$, ヘモグロビン $17.5 \mathrm{~g} / \mathrm{d} l$, へマトクリット $51.6 \%$ と多血症を認めた. 動脈血ガス分析では room air で $\mathrm{PaO}_{2}$ 39.8Torr, $\mathrm{PaCO}_{2}$ 32.9Torr, $\mathrm{SaO}_{2} 75.4 \%$ と低 酸素血症を認めた（表 1 ）。心電図には異常所見はな かった。

胸部 X 線写真では左中肺野に結節状陰影が瘁合し たと思われる塊状陰影と，左下肺野に結節状陰影を認 めた。右肺門部之右中肺野外側にも各 1 個の結節状陰

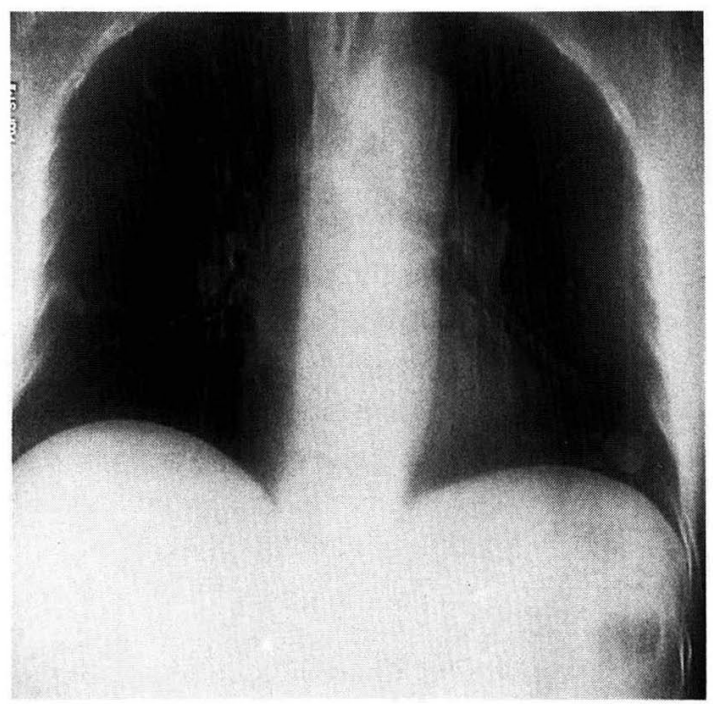

A 背側より $10 \mathrm{~cm}$
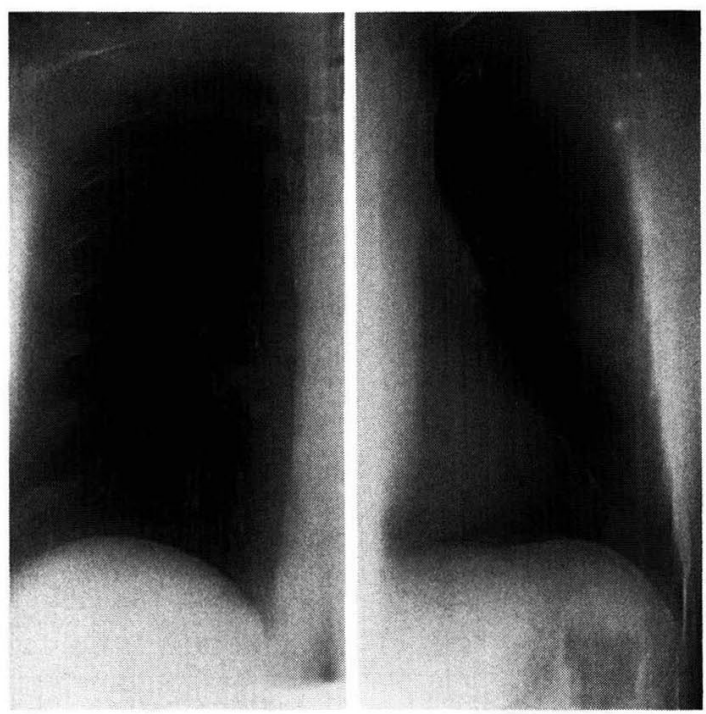

B 左肺：右肺：背側より $5 \mathrm{~cm}$, 背側より $15 \mathrm{~cm}$

图 3 胸部断層写真 
影を認めた（図 2 )。断層写真で左の $\mathrm{S} 3 ， 4 ， 5 ， 8$ と右 の $\mathrm{S} 6,8$ 亿結節状陰影打よび流入動脈, 流出静脈之考兵 られる陰影を認めた（図 $3 \mathrm{~A} ， \mathrm{~B}$ ）。

胸部 CT でも左の S3，4，5，8 と右の S6，8に結節状 陰影と流入動脈, 流出静脈を確認した。図 4 にその一 部を示した。100\%酸素吸入下での動脈血ガス分析は $\mathrm{PaO}_{2}$ 47.8Torr, $\mathrm{PaCO}_{2} 36$.1Torr, $\mathrm{SaO}_{2} 83.2 \%$ であ り $\mathrm{AaDO}_{2}$ 629.1Torr, シャント率は簡便法により $56.5 \%$ あった。以上の所見上り多発性両側性肺動静 脈㜢と診断した，高濃度酸素投与によっても改善しな い著明な低酸素血症を認めたことより、シシント量が 大きいと考觉られる左肺の肺動静脈㾇切除を目的とし た肺部分切除を行った。

手術所見：右側臥位, 後側方切開にて開胸し左肺上 下葉間を剝離した。引き続き $\mathrm{S} 3 ， 4 ， 5 ， 8$ の肺動静脈瘦 を中心とした部分切除を行い健常肺組織は可能な限り 温存した（図 5 )。術直後100\%酸素吸入下での動脈血
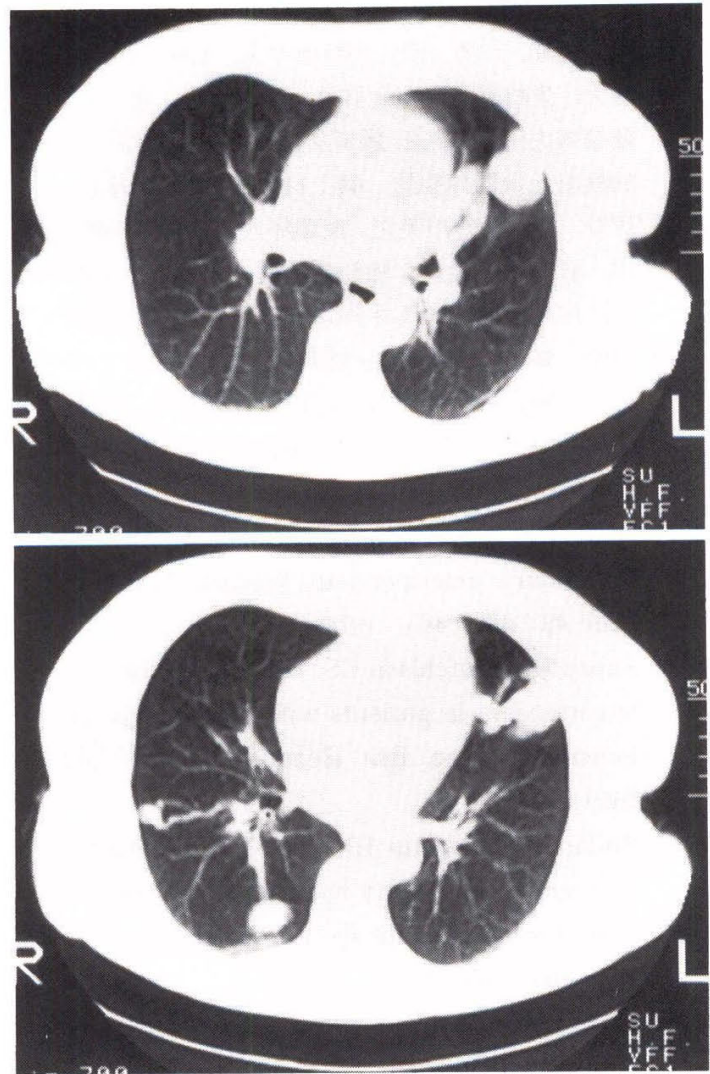

図 4 胸部 CT 写真：左肺 S3 (上段), 左肺 S4, 右肺 S6, 8 (下段) に肺動静脈癨を認める.

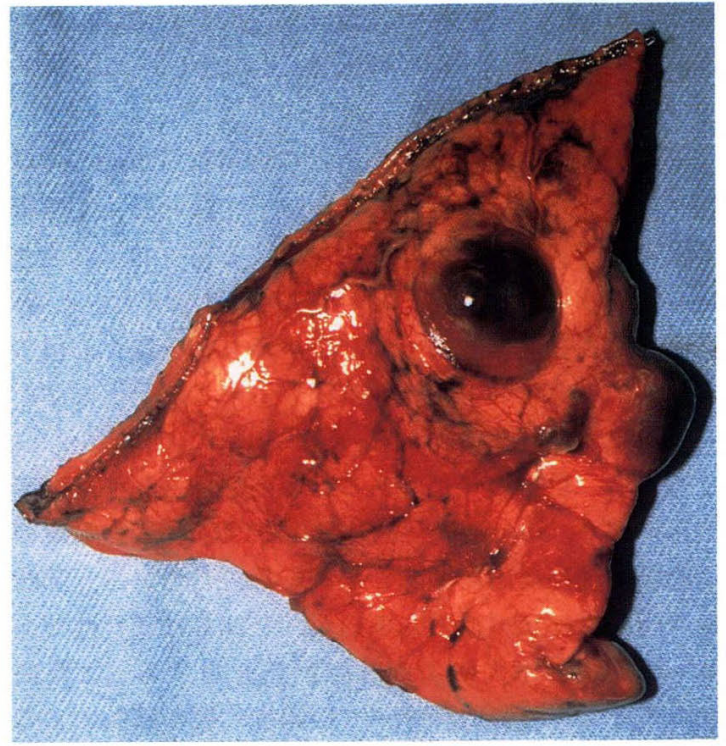

図 5 切除肺左肺 S3，4，5の肺動静脈癏を示す。

ガス分析は $\mathrm{PaO}_{2}$ 80Torr, $\mathrm{SaO}_{2} 93 \%$ と著明に改善し た.

\section{考察}

肺動静脈濡とは肺内の動脈采と静脈䒺が短絡をおこ す比較的稀な疾患である。病因は中肧葉性の血管形成 不全による肺毛細血管の欠如と考えられている。この ため肺動静脈瘦は Rendu-Osler-Weber 病（遺伝性出 血性毛細血管拡張症) との関連が指摘されている. Bo-

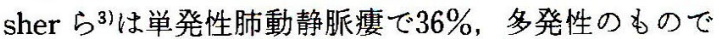
$57 \%$ が Rendu-Osler-Weber 病と合併していたと報告 している. 本邦では肺動静脈瘦と Rendu-Osler-Weber 病との合併は欧米の報告に比べて少なく，斎藤ら $3.2 \%$ ，伊藤らが $12.1 \%$ と報告している。しかし，家 系を詳細に調查することにより肺動静脈㾇の 4 症例の 全てに Rendu-Osler-Weber 病の家系を認めたとの報 告6) むる。本症例は，(1)末梢毛細血管抬張（口腔粘 膜) - (2)出血傾向 (鼻出血) - (3)家族歴 (筧祖母が鼻出 血で死亡. 祖父, 祖父の兄弟, 母親, 妹，4人の子供 全てに鼻出血傾向.）を示すことより Rendu-OslerWeber 病と診断し，それに伴う多発性肺動静脈㾇であ ると考えられた。

肺動静脈瘦の診断年齢は斎藤ら た190例の報告によれば, 10歳台が最も多く，30歳台ま でに約70\%の症例が診断されている４0歳を過ぎると 
徐々に減少し，40歳台では $11.5 \% ， 50$ 歳台では $8.9 \%$, 60歳台では $5.7 \%$ であり，70歳以上では 1 例（0.5\%） を認めるにすぎない。

肺動静脈瘻の手術適応としては1974年, Dines ら7)は 以下のような規準を提唱している。すなわち，(1)呼吸 困難やチアノーゼなどの症状を呈するシャントが大き い瘻を有する患者, (2)増大傾向のある瘻を有する患者, (3)両側性多発性のものでは, 肺組織を充分温存し得る 摘除によりシャント率の改善が見込める限局性の瘻を 有する患者, (4)体循環からの流入動脈により瘻を形成 する患者．以上の 4 つである，手術禁忌としては肺高

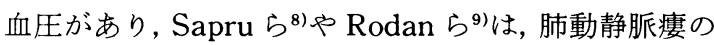
切除後に肺高血圧が増悪した例を報告している。肺動 静脈瘦は無症状のことも多いが，しばしば進行性であ クシャントの増大による呼吸困難を呈する。また血 栓・塞栓などの脳血管障害や脳膿瘍, 瘦の破裂による 出血などの合併症も起こす。このため自然観察された 場合, Muri ${ }^{10)}$ によると瘻破裂により50例中 7 例が死亡 している。多発例では外科的治療を受けなかった場合 Currariano ら ${ }^{11}$ によれば18例中 7 例が25歳までに死 亡し, Dines $ら^{7)}$ によれば約 6 年の期間に 5 例中 2 例が 死亡したと報告されている。したがって岩ら ${ }^{12)} は$, 肺高 血圧合併例や，高齢者など特別な例を除き可能な限り 手術を行らべきであると述べている，最近，塞栓術に よる治療例 ${ }^{13) 14)}$ が報告されており，外科的切除ができ ない多発性両側性の症例などの治療に有用である。 た塞栓術と外科的切除術を組み合せることにより，今 後手術適応の範囲がさらに拡大寸るものと考兄られ る.今回の症例は 70 歳と高齢ではあったが，低酸素血 症が急速に増悪し，生命維持が困難と考号られたため 手術を施行した。呼吸困難の急激な变化を来す前に撮 影された 1989 年12月, 及び1990年 8 月の胸部 X 線写真 と比較したところ, 瘦が写真上判定できる程急速に増 大してはいなかった。従って，最近になってシャント 率が急激に増加したものとは考光がたく，呼吸困難の 急速な悪化を示した原因としては，1990年 9 月の旅行 前に既にシャント率は呼吸不全を示す限界近くに達し ていたものと考学られる。更に，旅行中に徐々にシャ ント率が增加し， $\mathrm{SaO}_{2}$ の低下を招き，旅行による運動 負荷と相まって意識消失を来す程の呼吸不全をきたし たものと思われた。術後経過は良好であり, 自覚症状・ 動脈血ガス分析所見・シャント率等は著明に改善した。 Gautam ら ${ }^{15}$ の報告によれば両側性肺動静脈瘻の場 合, 一側手術後, 残りの一側を手術する待機中に遺残
肺動静脈瘻の出血により死亡した例も存在する。この ため今回の症例においても今後右肺の遺残肺動静脈瘻 の注意深い経過観察が必要であると思われる.

われわれは今回70歳と高齢の多発性両側性肺動静脈 瘦の手術例を経験し，手術適応を考吕る上での貴重な 症例と思われたので報告した。

謝辞：本症例の手術を担当された, 本学第二外科高橋広 講師と中央手術部長永井勲助教授に感謝します。

\section{文献}

1) Churton $T$ : Multiple aneurysm of pulmonary artery. Brit Med J 1 : 1223, 1897.

2）佐野寛二, 打越慶三, 吉見静夫：肺血管腫. 肺 1 : 219-223, 1954.

3) Bosher LH, Blake DA, Byrd BR: An analysis of the pathologic anatomy of pulmonary arteriovenous aneurysms with particular reference to the applicability of local excision. Surgery 45: 91-104, 1959.

4）斎藤道顕, 戸田 央, 小野田万丈, 高橋 敏, 白鳥 敏夫, 里村立志, 山添信幸, 鈴木 忠, 倉光秀魔, 織畑秀夫, 千葉成宏, 飯田文良：肺動静脈瘻の臨床 的検討. 日臨外会誌 $44: 1147-1152,1983$.

5）伊藤 進, 長谷川英之, 後藤隆人, 菊地福三郎, 井 出 研, 吉村義之: 肺動静脈瘦の 1 例と本邦66例 の臨床的検討。日臨外会誌 $39 ： 735-742,1978$.

6）桑原 修, 松村晃秀, 土肥英樹, 中川芳樹, 上田英 之助：肺動静脈瘦からみた遺伝性末梢血管拡張症 （Osler 病）と家系調査の意義. 日胸外会誌 35 : 804-809, 1987.

7) Dines DE, Arms RA, Bernatz PE, Gomes MR: Pulmonary arteriovenous fistulas. Mayo Clin Proc 49: 460-465, 1974.

8) Sapru RP, Hutchison CS, Hall JI: Pulmonary hypertension in patients with pulmonary arteriovenous fistilae. Brit Heart J 31:559-569, 1969.

9) Rodan BA, Godwin JD, Chen JTT, Ravin CE: Worsening pulmonary hypertension after resection of arteriovenous fistula. Am J Roentgenol $137: 864-866,1981$.

10) Muri JW: Arteriovenous aneurysm of the lung. Am J Surg 89:265-271, 1955.

11) Currarino G, Willis $W$, Johnson AF, Miller $W$ : Pulmonary telangiectasia. Am J Roentgenol 


$$
127: 775-779,1976 .
$$

12）岩喬, 村上犋也, 渡辺洋宇 : 肺動静脈瘻. 呼吸 $6: 1314-1318,1987$.

13) Chilvers ER, Whyte MKB, Jackson JE, Allison DJ, Hughes JMB : Effect of percutaneus transcatheter embolization on pulmonary function, right-to-left shunt, and arterial oxygenation in patients with pulmonary arteriovenous malfor- mations. Am Rev Respir Dis $142: 420-425$, 1990.

14) Wallenhaupt SL, D'Souza V: Combined radiological and surgical management of arteriovenous malformation of the lung. Ann Thorac Surg 45:213-215, 1988.

15) Gautam HP: Pulmonary arteriovenous fistula. Int Surg 46:168-175, 1966.

Abstract

\title{
A Senile Patient with Rendu-Osler-Weber Disease who Underwent Resection of 4 Multiple Bilateral Pulmonary Arteriovenous Fistulas
}

\author{
Kazuaki Mineoi, Seiji Fujioka, Hiraku Ichiki, Takeru Iwata, \\ Nobuoki Kohno and Kunio Hiwada
}

A 70-year-old female patient with multiple bilateral pulmonary arteriovenous fistulas was referred to our hospital for its treatment. She had experienced frequent epistaxis and had nasopharyngeal telangiectasia. Her mother, sister and all four children also suffered from epistaxis. We diagnosed this patient as Rendu-OslerWeber disease combined with multiple bilateral pulmonary arteriovenous fistulas. Her chest roentgenogram revealed 4 arteriovenous fistulas in the left lung and 2 arteriovenous fistulas in the right. On admission

The Second Department of Internal Medicine, Ehime University School of Medicine arterial blood gas analysis while breathing room air showed a $\mathrm{PaO}_{2}$ of 39.8 torr and an $\mathrm{SaO}_{2}$ of $75.4 \%$. The percent of R-L shunt was calculated to be $56.5 \%$. Because of severe hypoxemia, she underwent resection of four large fistulas in segments $3,4,5$, and 8 of the left lung. Twenty-eight days after the operation, the $\mathrm{PaO}_{2}$ was 76.4 torr and $\mathrm{SaO}_{2}$ was $95.7 \%$. There was no sign of enlargement in size of the remaining arteriovenous fistulas.

key words: multiple bilateral pulmonary arteriovenous fistulas, senile patient, operation therapy, hypoxemia, Rendu-Osler-Weber disease

(Jpn J Geriat 28: 697-701, 1991) 